\title{
O eu e o outro na violência do assalto: (im)possibilidades de constituição subjetiva na e pela linguagem
}

\author{
Valéria Aparecida de Souza Machado ${ }^{1}$
}

\begin{abstract}
RESUMO: Este trabalho analisa o tratamento da violência nos contos "Dentes negros e cabelos azuis" de Lima Barreto e "J. C. J." de Marcelino Freire, tendo como foco o assalto. Será investigado, textualmente, como se constituíram as relações entre assaltante e assaltado - agente e paciente. Levando-se em conta a constituição de subjetividades através da linguagem, serão verificadas as (im)possibilidades de emersão do sujeito na relação empreendida no assalto.
\end{abstract}

ABSTRACT: The purpose of this work is to analyze the handling of violence in the short stories "Dentes negros e cabelos azuis" by Lima Barreto and "J. C. J." by Marcelino Freire, having the assault as the center of interest. Textually, it aims to investigate how the relations between the assailant and his victim - agent and patient - are built. Taking into account the constitution of subjectiveness through language. The (im)possibilities of emergence of the subject in the relation produced by the assault will be investigated, as well.

PALAVRAS-CHAVE: Literatura; Violência; Assalto; Espaço; Linguagem; Sujeito KEYWORDS: Literature; Violence; Assault; Space; Language;Subject

Um ato de acolhimento: dar ao menos um olhar, conceder um olhar, pôr os olhos sobre alguém, deitar-lhe um olhar - tudo vem a ser prestar atenção, o que é um sinal ou uma esperança de favor [...] Se não de benévola aceitação. (BOSI, 1988, p.78).

\footnotetext{
${ }^{1}$ Mestre em Literaturas de Língua Portuguesa pela PUC/Minas Gerais. Dissertação: "O eu e o outro na violência do assalto: vozes e olhares que se (re) velam no espaço do texto".
} 
Falar sobre a violência é, em grande parte, pisar em terreno árido e também escorregadio, já que trata-se de fenômeno complexo, intrínseco ao próprio movimento sociopolítico e econômico, e que assume diferentes modalidades de manifestação na produção cultural das sociedades. Por isso mesmo, optou-se, neste trabalho, por analisar o tratamento do tema da violência tendo como foco o assalto e os sujeitos aí envolvidos - assaltante e assaltado -, em narrativas brasileiras produzidas em épocas distintas. Escolheu-se, como corpus para análise, os contos: "Dentes negros e cabelos azuis", de Lima Barreto e “J. C. J.”, de Marcelino Freire.

Tomando o assalto como um acontecimento que coloca uma pessoa diante da outra, de forma súbita, envolvendo um agente - o assaltante - e um paciente - o assaltado - e, além disso, uma ação que pode envolver relações de força de ambos os lados, importa analisar os contos buscando-se verificar, textualmente, como se construíram as relações entre assaltante e assaltado em diferentes épocas e contextos de produção. Por isso mesmo, optou-se por aproximar a relação entre assaltante e assaltado do próprio processo de interação verbal com o intuito de perceber em que medida essa relação abre possibilidades para que o sujeito possa emergir, tendo assegurada sua consciência enquanto tal. Tomando emprestados alguns aspectos importantes da teoria da enunciação (BENVENISTE, 1989, 2005; BAKHTIN, 1981), bem como examinando o processo enunciativo no que se refere a quem fala, como fala e de onde fala, a análise observa de que forma ocorre a interação entre assaltante e assaltado, sem deixar de considerar que essa relação pode nem sempre ser verbal e positiva, impossibilitando a subjetividade de pelo menos um dos envolvidos. Assim, é importante perceber em que situações há choque ou ruptura na relação que o assalto envolve, na medida em que um EU, como sujeito, não possibilita que o outro (TU) também se constitua como sujeito.

É importante considerar que, enquanto acontecimento, o assalto também envolve espaços diversos, mas invadidos. A própria invasão de 
um espaço que pertence ao outro já se configura como uma forma de violência. Parte-se, pois, do pressuposto de que se a relação EU-TU não se estabelece pelas vias normais, isto é, por um processo de interação em que ambos possam falar e ser ouvidos, aquele que não se sente capaz de ser sujeito é impelido a invadir o espaço do outro, talvez como forma de se tornar visivel a esse outro. Sua alternativa seria, então, o uso da força e da violência.

Levando-se em conta que o que se privilegia nesta análise é a questão da constituição do sujeito na relação EU-TU, os aspectos relacionados ao tempo e ao espaço serão abordados em sua perspectiva relacional, ou seja, as relações dos sujeitos no tempo e no espaço, no exercício da linguagem. Cabe destacar que tudo isso não deixa de fora a discussão acerca da dissolução do espaço público e a soberania do espaço privado onde a violência se inscreve como invasão para revelar um sintoma de relações rasuradas.

Considerando-se a literatura palco de encenação da linguagem por excelência, propõe-se a análise do processo enunciativo dos contos selecionados, de modo a ver como são construídas tais relações entre agente e paciente do assalto - investigando sua natureza de sujeitos ou objetos -, bem como de que forma e por quais vias o sujeito se constitui no texto e pelo texto.

Em "Dentes negros e cabelos azuis" duas narrativas se entrecruzam. A primeira traz a história de Gabriel, contada pelo narrador que é seu único amigo, e fala de sua natureza triste e solitária. Gabriel vivia isolado, dividido entre as coisas sublimes, que moviam seu espírito inteligente e sensível, e a atração pelas coisas do mundo, na busca de satisfações materiais, o que transformava sua vida num acúmulo de desastres. A segunda narrativa, escrita pelo próprio Gabriel, conta sua história utilizando a caricatura: um homem que tinha dentes negros e cabelos azuis e, por isso, sofria a hostilidade e a discriminação de seus semelhantes que não reconheciam nem aceitavam sua diferença. Certa noite o homem é abordado por um 
assaltante que, depois de lhe tomar o dinheiro, assusta-se ao perceber sua anomalia. Condoído com tal situação, o assaltante devolve-lhe o dinheiro roubado e, então, estabelece-se um diálogo amistoso entre eles, levando cada um a falar de suas desventuras e esperanças.

O conto “J. C. J.” relata uma situação de violência comum no cotidiano das grandes cidades: um menino de rua, "cheirado à cola", aborda uma mulher pela janela de seu carro parado no sinal de trânsito, na tentativa de assaltá-la. Negando dar ao menino até mesmo uma moeda, a mulher responde com um palavrão, cuspindo-lhe na cara. Como resposta, o menino investe contra a mulher cortando-lhe o pescoço com um caco de vidro. Enquanto ela agoniza com o sangue que lhe escorre da veia, os motoristas ao lado seguem, apressados, o seu destino, sem lhe prestar socorro. Além de abandonada no meio da rua, a mulher também é vítima de um assalto praticado por um terceiro, um homem que olhava tudo do posto de gasolina e que se aproveita do tumulto da situação para roubar-lhe a bolsa, levando seu dinheiro e seus documentos.

Um traço comum que se observa nas narrativas analisadas é a delineação do personagem em sua relação com o contexto urbano relatado. Os personagens constituem-se em testemunho de dado contexto social, mas também revelam mágoas, tensões e conflitos individuais, decorrentes das relações que se estabelecem entre eles e com seus lugares. Em "Dentes negros e cabelos azuis", narrador e personagens, associados ao cenário urbano, vão caracterizar o homem e a cidade moderna. Os personagens dizem muito do individuo ressentido pelas desigualdades que afetam a vida urbana, desintegrando o homem e o corpo social do qual ele faz parte, como se observa no comportamento "dual" do personagem Gabriel:

[...] o seu caráter e a sua organização muito concorriam para sua dorida existência. Muito inteligente para amar a sociedade de que saíra, e muito finamente delicado para se contentar de tolerado em outra qualquer, Gabriel vivia isolado, bastando-se a si mesmo e aos seus pensamentos, como um estranho anacoreta que 
fizesse do agitado das cidades, ermo para seu recolhimento. (BARRETO, 1990, p. 202).

Personagens e cidade, juntos, traduzem a degenerescência, o lado sombrio e degradado da vida humana moderna, apontando, muitas vezes, para homens melancólicos que fogem e se escondem em um mundo criado para si, a exemplo do personagem Gabriel:

[...] indiferente às pequeninas cousas do mundo, céptico a seu modo; mas, em breve sob essa máscara de polidez, fui percebendo nele um queixoso, um amargo a quem uma melancolia, provinda de fugitivas aspirações para satisfações impossiveis, revestia de uma tristeza coesa. (BARRETO, p. 202).

Na modernidade, já se observam movimentos de marginalização como espaços destinados aos indivíduos explorados e alijados pela sociedade - que compõem o cenário textual no desenvolvimento da literatura urbana, como se vê no conto de Lima Barreto. A violência representada nesses espaços pode ser compreendida como a simbolização de conflitos sociais que surgem no ambiente urbano, já dividido em centro e periferia. Outrossim, outros elementos se agregam ao texto, conferindo-lhe uma complexidade que compreende aspectos da subjetividade inerente ao estar do homem no mundo.

Em "Dentes negros e cabelos azuis" as características dos personagens e seu estado emocional e interior são enfatizados para marcar os contrastes da cidade dividida em centro e subúrbio. Esse recurso parece reforçar a pretensão autoral em mostrar as desigualdades entre os diversos níveis sociais e colocar em relevo as dificuldades de interação entre homens diante dos entraves impostos pela vida em sociedade:

[...] passeava, vagava horas e horas, tímido, covarde, encostado a um canto, pensava, sofria à menor risota e o mais imbecil dito cortava-me a alma. Era a constante preocupação das minhas ideias passar o meu sofrimento, a outra pessoa, evitá-lo detidamente a alguém. Sob a pressão daquela mágoa eterna, no meu íntimo ficava o segredo exigente de comunicação [...] meu 
espírito se perdia, caía em devaneio [...] do homem ia aos cães, aos gatos, às aves, às plantas, à terra, em busca de confidente. (BARRETO, p. 204).

A violência, no conto de Lima Barreto, revela-se nas bordas do texto, nas imagens da cidade, dos personagens e de sua história. Imagens que apontam para uma violência sutil e muito mais ampla que ronda a sociedade, entrevista na segregação social de que são vítimas os personagens, a exemplo da mágoa que acomete Gabriel por trazer o estigma da discriminação e do preconceito:

Se, em dia claro e azulado, continuei, vou por entre árvores, crendo-me só e feliz, o miserável rafeiro que passa, deixa a inexorável busca do osso descarnado, para olhar as caretas do símio em que desdobro e ri-se de mim, meio espantado, mas satisfeito [...] Há por toda parte zumbidos, alaridos, risotas [...] e na sua vileza não escolhem palavras, não ensaiam deboches, gritam: mostrengo, vergonha da terra. (BARRETO, p. 208-209).

Mesmo assim, percebe-se que o conto de Lima Barreto guarda um tom mais leve, menos agressivo, mais marcado pelo humanismo. $\mathrm{O}$ assaltante, que invade o espaço do outro para the tomar o dinheiro, de fato, rouba-lhe outra coisa na medida em que o ser privilegiado é desnudado para se ver em sua miséria e fraqueza. O olhar do assaltante penetra naquilo que há de mais escondido no narrador:

[... É que as suas palavras relembravam-me toda a minha existência envenenada por aquele singular acidente; as desastrosas hesitações de que ela ficara cheia; o azedume perturbador, ressaibo do ódio e de amarguras de que estava tisnado. Os suplícios a que meu próprio espírito impunha. E de uma só vez, baralhado tudo isso se ofereceu aos olhos como uma obsessão demoníaca, algo premente, cruel [...] (BARRETO, p. 206).

Já o conto de Marcelino Freire vai lidar com espaços e problemas ainda mais complexos. As novas formas de se relacionar com o espaço urbano - mais fragmentado - abala as antigas referências do indivíduo que, ao tentar interagir com esse espaço, percebe sua própria 
identidade em crise. Cidade e sujeito são delineados em cenas soltas e dispersas. Não é possível perceber uma realidade social em sua totalidade. Apesar da diversidade e da pluralidade do espaço, os personagens constituem-se muito mais anônimos, sem conseguirem estabelecer uma sintonia entre si, como ocorre no encontro entre o menino assaltante e a mulher assaltada:

Adolesce o menino de rua, o menino cheirado à cola, sem sapato e sujo [...] À mulher do carro ele se chega, reto e disforme em direção. Ela não sabe e abre a janela [...] abre a janela para dizer um palavrão [...]. (FREIRE, 2005, p. 123)

As prioridades não são mais as diferenças ou desigualdades, mas os conflitos e tensões que surgem por causa das diferenças.

A perspectiva adotada pelo texto de Freire opera no sentido de acolher a diversidade ao incorporar tanto a voz do menino assaltante, quanto da mulher a quem ele assalta. No entanto, ao acolher essa diversidade, o assalto surge como impossibilidade de interação no cenário urbano fragmentado, onde estão em jogo relações também desencontradas. A violência gratuita em J. C. J. é compreendida como troca, como resposta a uma outra violência (simbólica) recebida da mulher/sociedade e que se internaliza no menino para retornar em sua forma bruta: "[...] E ele, J. C. J., sem piedade exposta, só ferida e crosta, encosta a mão contra a cara dela [...] "Quero moeda, mocreia" - diz J. C. J. - tava ele uma pistola." (FREIRE, p. 123).

É interessante notar que a violência encenada em “J. C. J." já não se configura apenas como reação ou reivindicação de grupos excluídos por causa das desigualdades sociais. Trata-se de uma violência que, embora se manifeste também pela agressão física, encontra-se já disposta em todas as esferas sociais e intermedeia as relações cotidianas dos sujeitos.

No que se refere aos tempos e espaços e suas relações no texto, observa-se que no conto de Lima Barreto, as relações com o tempo são engendradas a partir dos personagens e do discurso enunciativo. Ainda 
que se percebam marcações do tempo cronológico - a exemplo do encontro dos dois personagens, que se dá após as duas horas da manhã e só termina quando o subúrbio começava a despertar - é o tempo do discurso que define a noção de tempo, tido como elemento de grande importância na busca do conhecimento do mundo e do próprio sujeito. Rememorando o passado - "incurável mágoa muito sofrida na mocidade" (BARRETO, p. 211) - cenas, espaços e experiências vão sendo (re)construídos na urdidura do próprio texto.

Em "J. C. J." o próprio recorte que Marcelino Freire faz do espaço urbano - o trânsito - muito já diz da pressa e da velocidade que move o sujeito pós-moderno. É no processo mesmo de construção da narrativa que esse tempo se materializa em "J. C. J.": enunciados incompletos se embaralham e se sobrepõem, parecendo representar o ruído do trânsito que pede pressa nas buzinas impacientes dos carros. Motoristas colocados no mesmo nível de objetos, também conduzem ao tempo condicionado pelo espaço e submetido às regras da sociedade consumista que privilegia o objeto em detrimento do sujeito. Note-se que na construção "os buzinam" parece que o artigo 'os' ocupa o lugar de sujeito - aqueles que buzinam - levando os motoristas a fundirem-se com o carro que dirigem. O trânsito aparece, assim, como metonímia do espaço urbano pós-moderno, traduzindo a inconsistência das relações de sociabilidade entre os habitantes/passantes que, preocupados com o mundo objetivo e material, acabam por reduzir o acontecimento urbano a banalidades. Ressalte-se, no entanto, que, mesmo mimetizando o tempo da velocidade e da urgência, a própria escrita de Freire parece resistir a ele, ao se valer de recursos que aproximam o conto do universo da poesia e, também, ao utilizar o discurso indireto livre para evidenciar o tempo interior e psicológico do personagem, que escapa ao controle do tempo cronológico.

O espaço é outro elemento que se configura de modo diferenciado nos contos. Percebe-se, por exemplo, que no conto de Lima Barreto o espaço geográfico ganha certa importância na composição do cenário, 
apontando, alegoricamente, para a cidade, descrita como penumbra e composta de paisagens sombrias:

[...] Pelos seus trinta e quatro anos, eu o procurava em sua casa, uma pequena casinha, numa rua da ponta do Caju, junto daquele mar de morte que beija as praias desse arrabalde, olhando defronte o cinzelado panorama das montanhas. (BARRETO, p. 203).

É também pela descrição da paisagem, do espaço físico, que os espaços sociais são delimitados, numa nítida separação entre centro e periferia:

Morava eu nesse tempo em rua remota de uma estação de subúrbio afastado. Sem calçamento e mal iluminada, eu a trilhava às desoras em busca da casa reconfortante. Afazeres, e, em geral, a exigência do meu temperamento pelo bulício, pela luz da cidade, faziam-me demorar nas ruas centrais.

(BARRETO, p. 204).

Ainda, em "Dentes negros e cabelos azuis", o espaço público ganha relevo e aparece como lugar de encontro, de troca e de relação com o outro, haja vista que o diálogo que se estabelece entre os personagens se dá no espaço da rua - espaço público por excelência.

O espaço que se apresenta fixo, determinado e mais totalizante em Lima Barreto, configura-se múltiplo, fragmentado e em constante movimento no conto de Marcelino Freire. Tomado pela velocidade e pela tecnologia, o espaço urbano rompe com a percepção de continuidade; não tem um núcleo definido já que é formado de muitos espaços, diluindo-se as fronteiras entre público e privado.

A apropriação, também fragmentada, dos espaços da cidade pelos sujeitos/personagens e seu rápido deslocamento entre eles, faz parecer que o espaço urbano se alarga, quando, de fato, o que se percebe é seu estreitamento, já que limita a interação entre os sujeitos. Estes não se fixam em um espaço determinado e passam a viver como anônimos que não se enxergam e não se reconhecem. No conto de Freire, esse comportamento se reproduz no próprio espaço privado, a exemplo dos motoristas fechados em seus carros. As referências comuns passam a 
ser a individualidade e o isolamento dos personagens que interagem mais com o espaço do que entre si, o que, por isso, resulta em relações fragmentadas. Enquanto a rua é, para o menino assaltante, o lugar por excelência do excluído: "Adolesce o menino de rua, o menino cheirado à cola [...] Amola, esmola todo dia todo santo carro [...]" (FREIRE, p. 123), ela representa um mero lugar de passagem para os motoristas fechados em seu mundo particular: "[...] O trânsito nos nervos e ossos [...] E se eu morresse agora? O coração concorda. Os carros concordam. Os táxis. As pessoas enformigadas [...]" (FREIRE,p. 125-126).

Resta falar sobre a constituição de subjetividades nos dois contos ou, ainda, sua impossibilidade pelo silêncio. Do material analisado, o que se constata é que apenas no conto de Lima Barreto houve a possibilidade de constituição de subjetividades no espaço encenado pelo texto. É interessante notar que no início do conto o narrador usa os pronomes ESSE e ELE para se referir a Gabriel o que, em princípio, coloca o personagem na posição de uma não-pessoa: "Era dos mais velhos, o conhecimento que eu mantinha com esse rapaz. [...] Nos primeiros tempos ele sempre me apareceu como uma pessoa inalteravelmente jovial [...]" (BARRETO, p. 202, grifos nossos). No entanto, construído aos poucos, esse personagem vai ser configurado de outra forma. O narrador tira-lhe a máscara para enxergá-lo em sua condição de sujeito, buscando compreensão para sua natureza "dual e bifronte". Aproximando-se mais dele como se trouxesse no olho uma lente progressiva, o narrador nomeia o personagem: “[...] Muito inteligente para amar a sociedade de que saira, e muito finamente delicado para se contentar de tolerado em qualquer outra, Gabriel vivia isolado [...]" (BARRETO, p. 202, grifo nosso). Trocando de papel e de posição na cena enunciativa, o narrador da primeira história sai do lugar de EU para ocupar o lugar de ouvinte/interlocutor na segunda, encadeada por um texto escrito, construído pelo personagem Gabriel que tem então a voz. Ocupando as posições de narrador e personagem, Gabriel conta sua história, enuncia-se através de sua própria boca e de 
suas próprias mãos: "[...] ele me leu o seguinte, escrito com letra miúda e irregular em duas dezenas de tiras de papel almaço, cheias de paixão." (BARRETO, p. 204).

No desvendamento do lado obscuro da cidade, a narrativa também revela a face indesejada do personagem Gabriel, rejeitada pela cidade central e por ele próprio ocultada como forma de fugir do sofrimento: "[...] Quando a percepção do meu estado, da maneira da minha existência, era mais clara aos meus olhos, arquitectava planos de fugas para lugares longinquos [...]" (BARRETO, p. 205). É, então, o assaltante que leva Gabriel a tomar consciência desse seu 'outro' que teima em se ocultar. Quando empresta seu olhar para que o outro veja a si mesmo, o assaltante permite que Gabriel se constitua como sujeito, consciente de sua miséria humana e também de sua condição de excluído. Do lugar de "bandido" e "opressor", o assaltante passa a ouvinte, interlocutor e parceiro naquilo que o narrador the comunica:

Esteve assim minutos até que percebeu que a expressão do meu rosto era de choro e que nele havia a denúncia de uma grande mágoa fatal. O meu interlocutor transmudou as contradições de horror estampadas nas suas feições, abrindo-as num dúlcido sorriso de bondade. (BARRETO, p. 207).

$\mathrm{Na}$ comunicação que se estabelece entre os dois personagens, cada qual muda de lugar para assumir a enunciação. De ouvinte e interlocutor, o assaltante passa a sujeito da enunciação para também dizer de si ao reconhecer-se oprimido, devorado por uma sociedade que também a ele hostiliza e rejeita, negando-lhe a oportunidade de ser sujeito e cidadão. Assim como em Gabriel, aflora no assaltante a consciência de seu anonimato, de sua indiferença em uma sociedade que não lhe respeita como cidadão porque é pobre, desempregado:

- Não me creias um miserável gatuno de estradas, um comum assaltante de ruas. Foi o momento que me fez. Emprego-me em mais altos "trabalhos", mas preciso de uns "miúdos" e, para obtêlos, o meio se impunha. Se me demorasse, a ocasião perdia-se. Bem sabes, a vida é um combate; se não se fere logo, morre-se. 
[...] (BARRETO, p. 207).

Interessante é notar que o assaltante é investido de valores que entram em choque com aqueles instituídos pela sociedade. Ao (re) conhecer a dor do outro, o assaltante também se enxerga como discriminado e rejeitado. Tomado por um sentimento de compaixão em relação ao narrador ele desiste de ser o causador de mais um tormento na vida do outro: "[...] Toma o teu dinheiro. [...] Vai... Tu és sem esperança. Vai-te... Desculpa-me." (BARRETO, p. 207). Compaixão e solidariedade, expressas através da palavra dirigida ao outro, tomam o lugar da "faca em punho" e do "bronze".

Registre-se, ainda, que o rosto é a parte do corpo privilegiada; os olhos e a boca aparecem reiteradas vezes como que para enfatizar a importância que a troca de olhares e de palavras assume na narrativa. Através da expressão do rosto os dois personagens revelam sentimentos, demonstram comportamentos:

Ouvindo isso eu o fitei com as pupilas em brasa e minha fisionomia devia ter tão estranha expressão de angústia que o ladrão fechou a sua e estremeceu. É que as suas palavras relembravam-me toda a minha existência envenenada por aquele singular acidente $[\ldots]$

$[\ldots]$

Olhei-o interrogativamente. O homem tinha o ar mudado. Os lábios estavam entreabertos, trêmulos, pálidos, o olhar esgazeado, fixo, cravado no meu rosto. Olhava-me como se olhasse um duende, um fantasma. (BARRETO, p. 206)

Vivendo situações diferentes e ocupando lugares sociais também diferentes - um, intelectualizado, empregado, frequentador do meio culto e letrado; o outro, pobre, desempregado, andarilho do subúrbio os dois personagens são muito parecidos. Fazem parte do drama da cidade moderna e são igualmente afetados pela violência simbólica que permeia essa sociedade. É, pois, na e pela palavra que os personagens se constituem como sujeitos: "Meu peito arfava, meus olhos deviam 
brilhar desusadamente. A animação passava de mim ao ouvinte. Ele todo vibrava às minhas palauras [...]" (BARRETO, p. 210). Ora ocupando a posição de $\mathrm{EU}$, ora de $\mathrm{TU}$, os dois personagens falaram e foram ouvidos e, desse processo comunicativo, ambos saíram diferentes. Não por acaso, o assalto perde o caráter invasivo e agressivo para dar lugar à palavra e os dois personagens puderam ocupar o lugar de sujeitos.

No conto de Marcelino Freire o jogo sonoro-semântico, ao conferir um tom ritmado e cadenciado ao texto, reforça um apelo de leitura, despertando a atenção do leitor através da percepção auditiva. Por exemplo, a escolha de palavras iniciadas pelo mesmo fonema na passagem "sem sapato e sujo" (grifos nossos), intensifica, pelo som, o estado de pobreza do menino. A sonoridade do texto, construída com as rimas, a repetição de fonemas, o uso livre e musical dos vocábulos, aproxima-o do universo lírico da poesia, mas parece guardar a ironia com que a narrativa se tece. A crueza e a violência da história que se narra sobre J. C. J. - o menino que "adolesce" - escondem-se por trás da acentuação de uma linguagem lúdica e musical, já que são esses os elementos usualmente empregados em narrativas sobre ou para a criança. Entretanto, o que ironicamente se desvela sob o tom lírico da narrativa é uma história de abandono, de não pertencimento a lugar nenhum, do desrespeito a uma criança que só experimentou a violência e a miséria, impedida de vivenciar de forma lúdica as experiências da infância.

Identificado no conto apenas pelas iniciais do nome - J. C. J. - o menino representa uma voz silenciada no tecido social; a ausência do nome por extenso sugere, além de sua menoridade, o seu anonimato. Como voz silenciada, é através da voz do narrador que a perspectiva do menino é trazida ao texto para mostrar uma experiência infantil marcada pela carência e pelo abandono. Entretanto, o conto mostra que, ainda que violentado, J. C. J. também pratica ações violentas, situação que evidencia a assimetria das relações sociais.

Nos limites de seu espaço - a rua - o menino transgride o espaço 
do outro na tentativa de se mostrar a ele. Assim, invade espaços privados como fez ao abordar a mulher. No entanto, de dentro de seu espaço privado invadido, a mulher não enxerga o menino em seu desamparo e nega o contato. Para se defender, agride. A lingua cospe saliva e palavras que aumentam a ferida do menino, diminuindo-o em sua condição de pessoa. A negação e a agressividade excluem; impedem que o menino seja visto e ouvido, confirmando seu lugar de não-pessoa na sociedade:

Ela diz que não tem, amém e merda, e mostra uma cara, gorda cara, e uma lingua pastosa que não sabe quanto custa cuspir na cara de alguém. Mesmo alguém assim, fininho, mesmo alguém assim desalguém. (FREIRE, p. 123-124)

Ironicamente, essa negação faz o menino crescer diante da mulher, e ele, ameaça: "Vou furar, velhosa, teu miolo". (FREIRE, p. 124) A fúria de J. C. J. não é pela moeda que não veio; não é pelo relógio que poderia se tornar um meio para matar a fome. É pela negação cuspida na cara e é devolvida à mulher com uma outra moeda, muito mais cara: a violência bruta: "[...] J. C. J., num golpe, lâmina. [...] Goela abaixo o sangue corre [...]". (FREIRE, p. 124)

Depois de sua 'pequena grandeza' o menino volta a ser do mesmo tamanho e vai embora, correndo, sem nada levar, "sumindo" na esquina da rua que é o seu pequeno/grande espaço. Reduzido novamente ao seu mundo, tornado de novo pequeno, o "menino nem nem", não se importa, como se o ato que acabara de cometer fosse mais um a fazer parte de sua rotina violenta de trocas: "Ainda vê o menino na dobra da esquina. Ele corre, pequeno, já sumindo. [...] Ela aponta, tonta. O menino nem nem." (FREIRE, p. 124)

A partir daí, o discurso narrativo muda de perspectiva. O espaço textual vai se abrindo para dar lugar à mulher, evidenciando o corpo e a voz que a morte diminui. O menino "se foi"; ela "aponta" no texto. A carência de J. C. J., exposta na violência sofrida e cometida, cede espaço à carência da mulher que "engorda" o espaço textual. A 
aproximação com a morte provoca um recuo à infância. A mulher lembra-se da mãe, como se chamasse para si o colo materno que pudesse ampará-la, como ela não fez com J. C. J. O doce simboliza uma carência que a mãe deveria suprir: "[...] Arroz-doce, adora arroz-doce. Deu sangue na boca. 'Mãe, faz pra mim arroz-doce'. 'Mas, minha filha, você está gorda', gorda, muito gorda. [...]”. (FREIRE, p. 125)

Como se pode ver, não se vislumbra, no conto de Freire, nenhuma possibilidade de construção de subjetividade para o menino assaltante. As trocas empreendidas pelos personagens têm a violência como resposta. Com sua voz silenciada, J. C. J. devolve o que recebe da sociedade e, de alguma forma, se faz ouvir através da violência, única linguagem que conhece.

$\mathrm{Da}$ análise das duas narrativas constata-se que o que em Lima Barreto é palavra e ação juntas, em Marcelino Freire é mudo; é a ação desgrudada da palavra que se transforma em um ato qualquer para a obtenção de um fim, conforme aponta Hannah Arendt (2009). O que poderia ser uma situação propícia a gerar conflito e discórdia no conto de Lima Barreto, opera em sentido contrário, quando, entrando em ação, a palavra gera o entendimento. Em Marcelino Freire é a violência que prevalece, já que violência é a palavra muda.

Em “J. C. J." a relação EU/TU surge como estilhaços, uma relação que se faz de cacos. J. C. J., socialmente destituído de voz e impossibilitado de ser visto e ouvido diante de interações impedidas e relações violentadas, mostra-se, para o outro, através da invasão de um espaço privado. A mulher, apesar de deter o direito de voz, também é vítima na medida em que, ao adotar as regras de conduta social, tem sua subjetividade suprimida. Desejos e vontades reprimidos resultam uma vida de vazios e carências, assim como em J. C. J. Em situações diferentes, ambos são vítimas, mas também vitimizam. Assaltante e assaltado relacionam-se, no conto, pela linguagem da violência.

É preciso pensar, no entanto, que o tom adotado pelos escritores, cada qual a seu modo, possibilitou que os personagens cuja voz foi 
silenciada pudessem constituir-se como sujeitos no espaço textual. Note-se que os dois contos relativizam, de alguma forma, a relação entre assaltante e assaltado, entre sujeito e paciente. No conto de Lima Barreto as relações são percebidas de uma forma em que se revela a tensão entre a individualidade e as forças/entidades sociais, privilegiando-se o sujeito, suas emoções e a percepção que ele tem do mundo. Em Marcelino Freire, a mulher mostra-se tão desvalidada quanto o menino. Apesar de aceitar as regras do jogo social, ela também é vista em seu desamparo e é também vítima de uma sociedade reificadora. A carência e a solidão da mulher, encenadas pelo conto no momento de sua morte, aproximam os dois personagens, já que o menino também é visto como um ser carente e solitário.

O que se constata é que, das situações e relações encenadas, apenas em "Dentes negros e cabelos azuis" parece abrir-se a possibilidade de emersão de subjetividades, constituídas durante o processo de interação verbal dos personagens que, assumindo cada qual o lugar do discurso, transformaram violência em palavra; voz em olhar e olhar em voz. Importa salientar, entretanto, que, no plano da enunciação textual, ao desnudar as relações entre as personagens, o conto de Freire aponta para a impossibilidade dessa construção subjetiva nos espaços sociais encenados, o que, de certa forma, confere a essa narrativa um lugar de encenação de eus silenciados. Lugar onde os personagens se fizeram sujeitos na e pela linguagem textual.

De todas as possibilidades de percepção da realidade abertas pelos contos, destaca-se a importância do modo como as narrativas construíram o olhar sobre aqueles sujeitos/personagens que a sociedade não quer ver ou ouvir. Sujeitos que no contexto de Lima Barreto (1990) - onde a cidade, como pólo modernizador, constituía-se em um espaço de prevalência de regras e códigos - sucumbiram à lei e à ordem ocupando um espaço à margem e, ainda assim, foram movidos por convicções que apostavam na união e na solidariedade como elementos capazes de mudar uma dada realidade social. Ou sujeitos 
que, no contexto mostrado em Marcelino Freire (2005) - onde a cidade não é só uma, onde a volubilidade dos acontecimentos e das próprias relações baniu não só as referências tradicionais, mas qualquer referência - já não se resignam a ocupar um lugar marginal, impondose nos vários espaços, senão para serem ouvidos, pelos menos para serem vistos.

Ao lançarem um olhar sobre a violência como ruptura ou transgressão das relações entre os homens, esses contos suscitam um incômodo, um mal-estar sobre o qual convidam o leitor a refletir. Os olhares que os atravessam apontam para o homem em constante relação com o seu tempo, na tentativa de entender as mudanças que ele sofre no decorrer de sua história. São olhares que, de modo diferenciado apontam, no entanto, para o mesmo sujeito: o sujeito que sofre e desconhece a origem da sua dor, mas que tenta encontrar uma forma de amenizá-la, ainda que para isso ele aceite o jogo imposto pelo mundo material ao qual se aliena.

\section{Referências bibliográficas}

ARENDT, Hannah. "Ação" in: ARENDT, Hannah. A condição humana. Trad. Roberto Raposo. 10 ed. Rio de Janeiro: Forense Universitária, 2009, p. 188-255.

ARENDT, Hannah. Sobre a violência. Trad. e ensaio crítico André Duarte. 3.ed. Rio de Janeiro: Relume Dumará, 2001.

BAKHTIN, Mikhail. "A interação verbal” in: BAKHTIN, Mikhail. Marxismo e filosofia da linguagem: problemas fundamentais do método sociológico na ciência da linguagem. Trad. Michel Lahud e Yara Frateschi Vieira. 2. ed. São Paulo: Editora Hucitec, 1981, p. 110127.

BARRETO, Lima. Contos reunidos. Rio de Janeiro: Garnier, 1990. (Coleção dos autores modernos da literatura brasileira;7). 
BARROS, Diana Luz Pessoa de; FIORIN, José Luiz. (orgs.). Dialogismo, polifonia, intertextualidade: em torno de Bakhtin. 2.ed. São Paulo: Edusp, 2003.

BAUMAN, Zygmunt. Globalização: as consequências humanas. Rio de Janeiro: Jorge Zahar Ed., 1999.

BENVENISTE, Émile. "A linguagem e a experiência humana" in: BENVENISTE, Émile. Problemas de linguística geral II. Campinas (SP): Pontes, 1989, p. 68-80. (Linguagem/Crítica)

BENVENISTE, Émile. "Da subjetividade na linguagem" in: BENVENISTE, Émile. Problemas de linguística geral I. Trad. Maria da Glória Novak e Maria Luisa Neri. 5. ed.. Campinas, SP: Pontes Editores, 2005, p. 284-293.

BENVENISTE, Émile. "O aparelho formal da enunciação" in: BENVENISTE, Émile. Problemas de linguística geral II. Campinas (SP): Pontes, 1989, p. 81-90. (Linguagem/Crítica )

BOSI, Alfredo. "A interpretação da obra literária” in: BOSI, Alfredo. Céu, inferno: ensaios de crítica literária e ideológica. São Paulo: Duas Cidades; Ed. 34, 2003, p. 461-479. (Coleção Espírito Crítico).

BOSI, Alfredo. História concisa da literatura brasileira. 2.ed. São Paulo: Editora Cultrix, 1975.

CANDIDO, Antonio. "A literatura e a vida social" in: CANDIDO, Antonio. Literatura e sociedade. 8. ed., São Paulo: T.A. Queiroz/Publifolha, 2000, p. 5; 16-17; 35. (Grandes nomes do pensamento brasileiro) CORTÁZAR, Julio. "Do conto breve e seus arredores" in: CORTÁZAR, Julio. Valise de cronópio. 2.ed. São Paulo: Perspectiva, 1993, p. 227237.

CUNHA, Antônio Geraldo da. Dicionário etimológico da Língua Portuguesa. 3. ed. Rio de Janeiro: Lexikon Editora Digital, 2007.

FERREIRA, Aurélio Buarque de Holanda. Novo dicionário da Língua Portuguesa. 2. ed. rev. e aumen. Rio de Janeiro: Editora Nova Fronteira, 1986.

FREIRE, Marcelino. “J.C.J.” in: FREIRE, Marcelino. Angu de sangue. 
2.ed. Cotia, SP: Ateliê Editorial, 2005, p. 123-126.

HABERMAS, Jünger. Mudança estrutural da esfera pública: investigações quanto a uma categoria da sociedade burguesa. Trad. Flávio R. Kothe. Rio de Janeiro: Tempo Brasileiro, 2003.

$\mathrm{KOCH}$, Ingedore Villaça. O texto e a construção dos sentidos. São Paulo: Contexto, 1997. (Coleção Caminhos da Linguística)

MURICY, Kátia. Alegorias da dialética: imagem e pensamento em Walter Benjamin. Rio de Janeiro: Relume Dumará, 1998.

PELLEGRINI, Tânia. "No fio da navalha: literatura e violência no Brasil de hoje" in: DALCASTAGNE, Regina (org.). Ver e imaginar o outro: alteridade, desigualdade, violência na literatura brasileira contemporânea. Vinhedo, SP: Horizonte, 2008, p. 41-56.

PELLEGRINO Hélio. "Psicanálise da criminalidade: ricos e pobres" in: Folha de S. Paulo, 1 de out. 1984, p. 7-8. (Folhetim).

PIGLIA, Ricardo. "Teses sobre o conto. Novas teses sobre o conto." in: PIGLIA, Ricardo. Formas breves. Trad. José Marcos Mariani de Macedo. São Paulo: Companhia das Letras, 2004, p. 87-114.

RESENDE, Beatriz. Dentes negros cabelos azuis: Lima Barreto e a cidadania em fragmentos. Rio de Janeiro: UFRJ- Departamento de Ciência da Literatura, 1989 (Tese de Doutorado).

RESENDE, Beatriz. "Lima Barreto: a opção pela marginalia" in: SCHWARZ, Roberto. Os pobres na literatura brasileira. (org.). São Paulo: Brasiliense, 1983. p. 73-78.

RONDELLI, Elizabeth. "Imagens da violência e práticas discursivas" in: PEREIRA, Carlos Alberto Messeder et alii. Linguagens da violência. Rio de Janeiro: Rocco, 2000, p. 144-162.

SANTOS, Luis Alberto Brandão; OLIVEIRA, Silvava Pessôa de. Sujeito, tempo e espaços ficcionais: introdução à Teoria da Literatura. São Paulo: Martins Fontes, 2001.

SANTOS, Milton. Metamorfoses do espaço habitado: fundamentos teóricos e metodológicos de Geografia. São Paulo: Editora Hucitec, 1988. 
SANTOS, Milton. Pensando o espaço do homem. São Paulo: Editora Hucitec, 1982.

SCHOLLHAMMER, Karl Eric. "Breve mapeamento das relações entre violência e cultura no Brasil contemporâneo" in: DALCASTAGNÈ, Regina (org.). Ver e imaginar o outro: alteridade, desigualdade, violência na literatura brasileira contemporânea. Vinhedo, SP: Horizonte, 2008, p. 57-77.

SCHOLLHAMMER, Karl Eric. "Os cenários urbanos da violência na literatura brasileira" in: PEREIRA, Carlos Alberto Messeder et alii. Linguagens da violência. Rio de Janeiro: Rocco, 2000, p. 236-259.

SEVCENKO, Nicolau. Literatura como missão: tensões sociais e criação cultural na Primeira República. São Paulo: Brasiliense, 1999.

WALTY, Ivete Lara Camargos. Corpus rasurado: exclusão e resistência na narrativa urbana. Belo Horizonte: Ed. PUC Minas/Autêntica, 2005.

WALTY, Ivete Lara Camargos; MENDES, Nancy Maria. Espaço e espaços: ensaios de semiótica, n. 14, dez. 1985, p.83-105.

ZIBERMAN, Regina. Estética da recepção e história da literatura. São Paulo: Editora Ática, 2004. 